\title{
Cave monitoring and the potential for palaeoclimate reconstruction from Cueva de Asiul, Cantabria (N. Spain)
} \author{
Steve R. Noble ${ }^{2}$, and Andrew Stott ${ }^{4}$ \\ ${ }^{1}$ Lancaster Environment Centre, Lancaster University, Lancaster, LA1 4YQ, UK \\ ${ }^{2}$ NERC Isotope Geosciences Facilities, British Geological Survey, Nottingham, NG12 5GG, UK \\ ${ }^{3}$ Centre for Environmental Geochemistry, University of Nottingham, Nottingham, NG7 2RD, UK \\ ${ }^{4}$ Centre for Ecology and Hydrology Lancaster, Lancaster, LA1 4AP, UK
}

Andrew C. Smith ${ }^{1,2^{*}}$, Peter M. Wynn ${ }^{1}$, Philip A. Barker ${ }^{1}$, Melanie J. Leng ${ }^{2,3}$,

\begin{abstract}
Palaeoclimate records from northern Iberia are becoming increasingly sought after as this region is one of the most southerly terrestrial locations in Europe to have its climate dictated principally by the North Atlantic. Terrestrial records therefore have the potential to offer insights into changing oceanic and atmospheric circulation in the wider North Atlantic region. Cave speleothems offer one of the most promising archives from northern Iberia due to their wide geographic distribution and potential for accurately dated climate reconstruction. Cueva de Asiul, situated in Cantabria (N. Iberia; 4319'0.63"N, 3³5'28.32"W; 285 m.a.s.I) within the Matienzo karst depression is one such site that offers the potential for palaeoclimate reconstructions. Here we present three years of climate and cave monitoring from Cueva de Asiul, giving detailed insight into local meteorology, hydrology and cave ventilation dynamics. In doing so, this paper presents a background to high resolution, Holocene duration speleothem records which have been extracted from this cave. Annual average cave temperatures are $+13.7^{\circ} \mathrm{C}$, with a maximum range of $1^{\circ} \mathrm{C}$, reflecting the seasonality of external air temperature (average external temperature $+13.8^{\circ} \mathrm{C}$ ). Cave ventilation is controlled by changes in external air temperature and variations in external air pressure during low pressure events. Local rainfall measurements show an average of $1400 \mathrm{~mm} /$ year with the majority of rainfall occurring during the winter, with periods of water excess between October and April. Speleothem drip rates are characterised by summer lows and a rapid transition to higher rates at the onset of the winter season. Stable isotope analysis $\left(\delta^{18} \mathrm{O}, \delta^{2} \mathrm{H}\right)$ indicate that aquifer water is derived predominantly from the previous year's rainfall and the rainfall feeding the karst system is controlled by a strong amount effect. Speleothems from this site are potentially suited to preserving extended records of rainfall amount in northern Spain and therefore have the potential to inform more clearly about Holocene scale changes in the rainfall source region, the North Atlantic.
\end{abstract}

Keywords: Cueva de Asiul, cave monitoring, palaeoclimate, speleothem, northern Spain

Received 20 May 2015; Revised 11 September 2015; Accepted 11 September 2015

Citation: $\quad$ Smith A.C., Wynn P.M., Barker P.A., Leng M.J., Noble S.R. and Stott A., 2016. Cave monitoring and the potential for palaeoclimate reconstruction from Cueva de Asiul, Cantabria (N. Spain). International Journal of Speleology, 45 (1), 1-9. Tampa, FL (USA) ISSN 0392-6672 http://dx.doi.org/10.5038/1827-806X.45.1.1928

\section{INTRODUCTION}

Cueva de Asiul is located in the Matienzo karst depression, Cantabria (N. Spain). The northern coastline of Spain is one of the most southerly locations in Europe to be predominately influenced by North Atlantic sourced weather systems (Gimeno et al., 2010). This region is therefore ideally placed to record variations in competing air masses and is of critical significance for understanding the role of the North Atlantic in controlling Europe's climate (Baldini et al., 2015). Current palaeoclimate records from this region are principally derived from lake (GonzalezSamperiz et al., 2008; Morellón et al., 2009; Roberts et al., 2012) or ocean sediments (Martínez-García et al., 2014, 2015; Mojtahid et al., 2013), cave speleothems (Dominguez-Villar et al., 2009; Moreno et al., 2010; Stoll et al., 2013; Martinez-Pillado et al., 2014; Baldini et al., 2015) and from archaeological evidence (LopezMerino et al., 2010). However, few of these records replicate at high resolution over long periods of time. Local sensitivity to atmospheric processes, orographic barriers and at some sites human interference, likely cause discrepancies within the records from this 
region. The accurate characterisation of northern Iberian climate change therefore requires the further production of high resolution palaeoclimate records from a diverse range of proxies.

Situated centrally in the north of the Iberian Peninsula, the Matienzo karst depression offers an ideal location for the preservation of speleothem palaeoclimate records from northern Iberia. The depression houses thousands of caves, which have developed sequentially throughout the last two million years (Waltham, 1981). This has resulted in an altitudinal controlled sequence of cave systems with the oldest located at the highest altitude within the depression. Speleothem deposits contained within each cave system thereby range in age, potentially dating from the time of the draining of active phreatic levels within the cave systems to the present day. Collectively, the Matienzo depression likely contains speleothem material which is an extraordinary repository of palaeoclimate archives from throughout the Quaternary.

However, to fully understand the climate and site specific karst/ cave processes which may govern the growth and chemical uptake of speleothems, cave monitoring must be undertaken on a site by site basis. In addition to understanding regional weather patterns, this work is focused on two major components of the cave climate system:

1) Soil and karst hydrology: the soil and karst zones facilitate or delay the transfer of rainfall into cave systems and by doing so regulate the timing and delivery of calcium carbonate rich water to actively growing speleothem deposits (Baker et al., 1997; Fairchild et al., 2006; Fairchild \& Baker, 2012). Hydrological changes therefore have the potential to influence both the rate of speleothem deposition and the extent to which speleothems incorporate accurate changes in external climate proxies (Dreybrodt, 1999; McDermott et al., 2004).

2) Cave ventilation: variations in air exchange between the karst, cave and external environments govern both cave air temperature and the carbon dioxide composition of cave air (e.g., Spötl et al., 2005; Smith et al., 2015). Whilst caves normally have a relatively stable air temperature, which reflects an average annual external value (Fairchild \& Baker, 2012) the $\mathrm{CO}_{2}$ composition of cave air can vary dramatically, both between sites but also at the same site during different times of the year (Mattey et al., 2010). Cave air $\mathrm{CO}_{2}$ content regulates the degassing of $\mathrm{CO}_{2}$ from drip waters and in doing so influences the rate of speleothem growth and potentially the uptake of chemical proxies into the carbonate lattice (Baldini et al., 2010; Mattey et al., 2010). It is therefore vital that we understand the dynamics of cave air temperature, $\mathrm{CO}_{2}$ and hydrology before assessing the suitability of speleothem deposits from any given cave as archives of palaeoclimate information.

We present three years of detailed cave monitoring from Cueva de Asiul, which allows for the characterisation of Matienzo climate and the cave climate system. This monitoring study underpins our main research goal, to present high-resolution speleothem records, offering information about climate change in northern Iberia and the role of North Atlantic weather systems in controlling European climate through the Holocene.

\section{REGIONAL SETTING AND SITE DESCRIPTION}

The production of palaeoclimate records through the analysis of speleothem deposits is becoming increasingly common in north western Iberia, especially so on the northern coastline. This interest has developed due to the regions close proximity to the North Atlantic and the ability of speleothems to record subtle changes in Holocene climatic conditions, linked to major variations in oceanic and atmospheric systems (Baldini et al., 2015). Currently, these reconstructions are somewhat restricted however, due to regional aridity in the mid Holocene when a large number of sites show a synchronous stop in growth of most speleothem deposits (Stoll et al., 2013). This has resulted in more focused studies which reconstruct smaller sections of the Holocene at high resolution (e.g. Dominguez-Villar et al., 2008; Dominguez-Villar et al., 2009; Martin-Chivelet et al., 2011; Baldini et al., 2015). Further work is required to find a cave site which may produce a more complete Holocene speleothem record from this region.

\section{Cueva de Asiul setting}

The Matienzo valley $\left(43^{\circ} 19^{\prime} 0^{\prime \prime} \mathrm{N}, 3^{\circ} 35^{\prime} 28^{\prime \prime} \mathrm{W}\right)$ is a $26 \mathrm{~km}^{2}$ closed karstic depression located in the Cantabrian Cordillera; within $40 \mathrm{~km}$ inland of the northern Iberian coastline in the province of Cantabria (Fig. 1). This mountainous region is mainly composed of uplifted Cretaceous sediments with E-W trending fault lines. The exploitation of these fault lines by chemical weathering has led to the formation of large karstic depressions (Quin, 2010) and hundreds of kilometres of cave passage (Corrin \& Smith, 2010). Cueva de Asiul (285 m.a .s.1), located on the northern slope of the La Vega arm of the depression (Fig. 1), is developed within thinly bedded Aptian limestone, broken by shallow sandstone lenses (Quin, 2010). The hydrological recharge area above the cave system is home to a small range of shrub and grass communities, only controlled by periodic grazing activities. Soil depths of $50 \mathrm{~cm}$ are common, with sections of bedrock exposed across the hillside.

\section{Cave description}

Cueva de Asiul is a small cave system, with a cave volume of close to $2.7 \times 10^{5}$ litres. The cave is horizontal, extending $75 \mathrm{~m}$ into the hillside in a north westerly direction. Access is via a small entrance $\left(<1.5 \mathrm{~m}^{2}\right)$, leading to a single passage with several high avens. The cave ends at $75 \mathrm{~m}$ at a calcited boulder choke (Fig. 2). No streams exist within the cave, but drip water fed pools are found at 40 and $60 \mathrm{~m}$ depth into the system and remain year round. The karst above the cave is relatively shallow (10-40 m rock overburden), with the most limited overburden toward the entrance and where high avens are observed. 


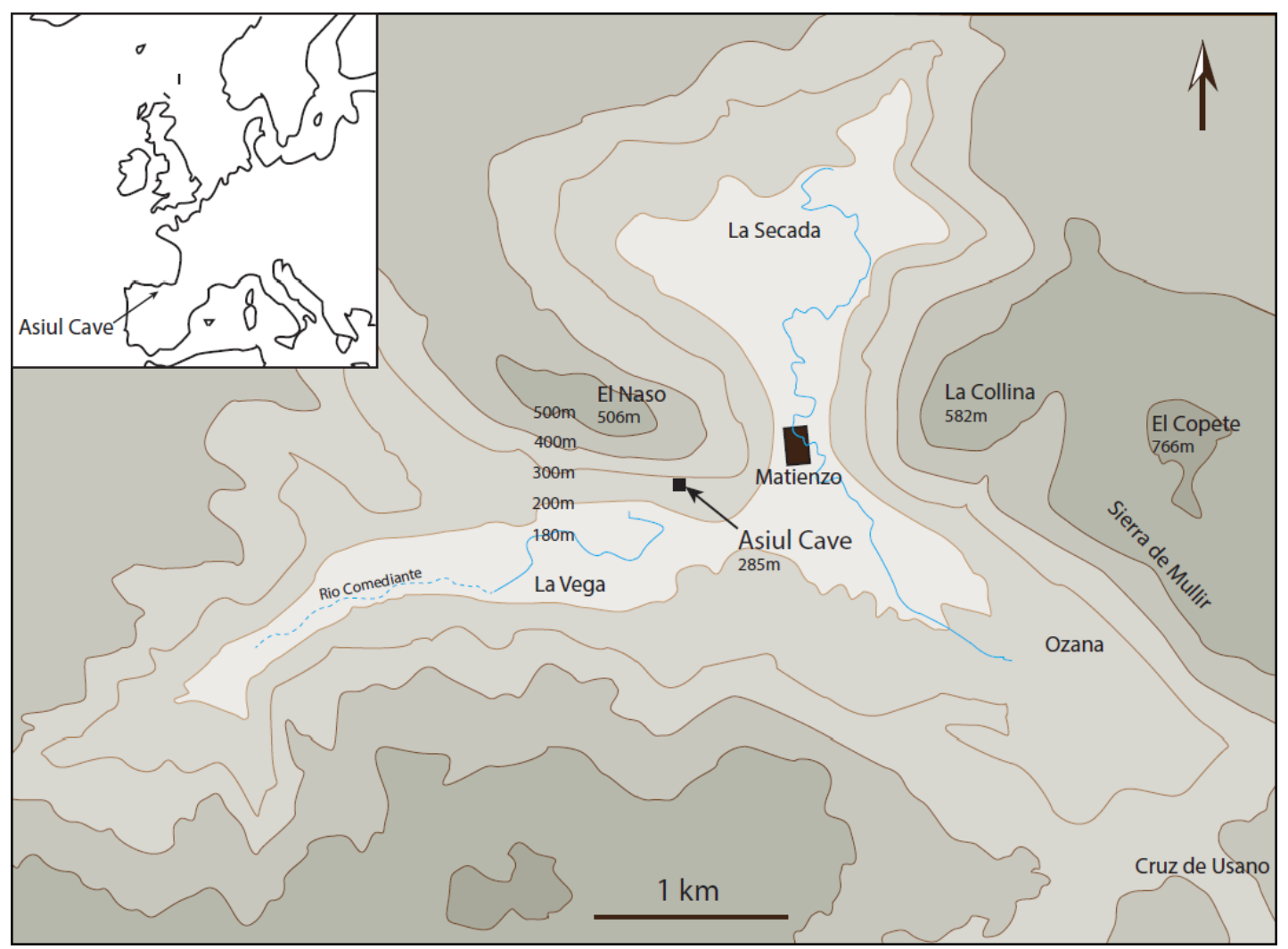

Fig. 1. Map of the Matienzo valley, including the site of Cueva d'Asiul and the village of Matienzo; reproduced from Smith et al. (2015).

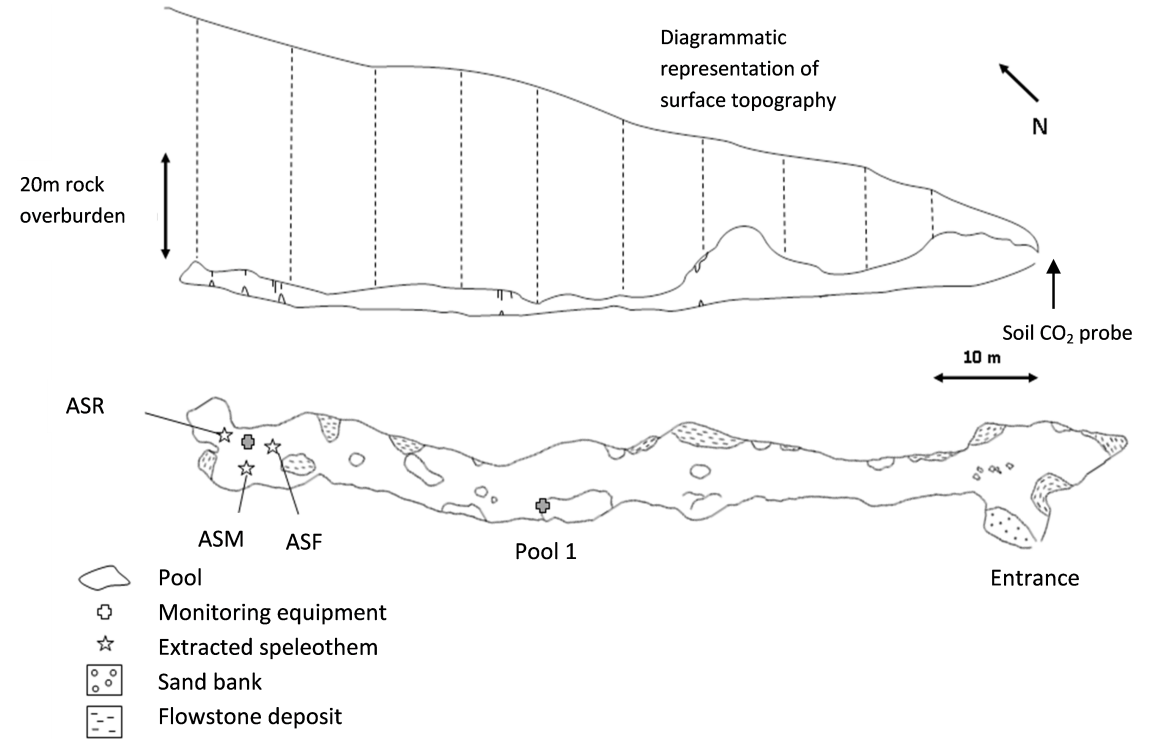

Fig. 2. Survey of Cueva d'Asiul (75 $\mathrm{m}$ total length) showing a floorplan of the cave with major cave pools and monitoring locations identified and rock overburden $(<40 \mathrm{~m})$ throughout the length of the cave profile; reproduced from Smith et al. (2015).

\section{CAVE AND CLIMATE MONITORING METHODS}

To characterise the contemporary cave environment in which these speleothems are currently growing, a three-year climate and cave monitoring programme was initiated in 2010. This programme included high resolution logging of cave and external air temperature, cave air $\mathrm{CO}_{2}$ content, cave air pressure, speleothem drip rate and drip water electrical conductivity (EC). In addition, sampling of event based rainfall allowed for the measurement of rainfall amount and isotopic $\left(\delta^{18} \mathrm{O}\right.$ and $\left.\delta^{2} \mathrm{H}\right)$ composition on a monthly scale. Monthly monitoring was also undertaken at the cave, including the measurement of soil air $\mathrm{CO}_{2}$ content, bulk drip water collection and the analysis of this water for $\mathrm{pH}, \mathrm{EC}$, temperature and isotope composition $\left(\delta^{18} \mathrm{O}\right.$ and $\left.\delta^{2} \mathrm{H}\right)$.

\section{External and cave air temperature}

External and cave air temperatures were measured from April 2010 using a TinyTag Plus2 logger recording every 30 minutes (measurement uncertainly $\pm 0.02^{\circ} \mathrm{C}$ ). External monitoring was undertaken within $250 \mathrm{~m}$ of Cueva de Asiul entrance, at $20 \mathrm{~m}$ higher altitude. Internal logging took place at $65 \mathrm{~m}$ depth into the cave system (Fig. 2). One logger was suspended $1 \mathrm{~m}$ above the ground free of any rock contact and a second was in direct contact with the cave wall. These loggers showed very little difference in temperature (within logger error); data presented here comes from the suspended logger.

\section{Rainfall and speleothem drip rates}

Measurements of rainfall amount were undertaken during rainfall collection in the village of Matienzo (1 $\mathrm{km}$ from the cave site and at $70 \mathrm{~m}$ lower altitude) from February 2011. $\delta^{18} \mathrm{O}$ and $\delta^{2} \mathrm{H}$ analysis of rainwater was undertaken via Isotope Ratio Mass Spectrometry (IRMS) at the NERC Isotope Geosciences Facilities using an Isoprime ratio mass spectrometer. Analytical errors reported at one standard deviation are $0.06 \%$ o for $\delta^{18} \mathrm{O}$ and for $\delta^{2} \mathrm{H}$ are $1 \%$, and are reported relative to VSMOW. 
Speleothem drip rate was measured at each of the main three speleothem sites (ASF, ASM and ASR). Drip rates were logged every ten minutes using acoustic Stalagmate drip loggers (Smith et al., 2015) from April 2010 (ASF) and May 2013 (ASR and ASM). Drip waters were also collected at each speleothem site as monthly bulk collections (a single container collecting all of one speleothems drip water for one month) for $\delta^{18} \mathrm{O}$ and $\delta^{2} \mathrm{H}$ analysis.

\section{Cave, soil and external air $\mathrm{CO}_{2}$}

Cave air $\mathrm{CO}_{2}$ was logged in the rear chamber of Cueva de Asiul every hour from February 2011 to November 2013 with one break in the record during the winter of 2011 due to logger malfunction. Soil $\mathrm{CO}_{2}$ was also measured from October 2011 to November 2013 at $50 \mathrm{~cm}$ soil depth (believed to be the junction between the soil and epikarst zones) using a right angled tube with a ventilated base section buried beneath the soil surface and vertical access port to enable gas samples to be extracted or $\mathrm{CO}_{2}$ levels to be measured (Fig. 3). The soil tube was installed into a trench in January 2011 and completely covered with soil and the pre-existing vegetation; visual recovery of the area was complete by the end of the summer season. Monthly and automated $\mathrm{CO}_{2}$ measurements of soil and cave air were taken using the same Vaisala Carbocap GM70 probe (working sensitivity of $\pm 10 \%$ of the reading).

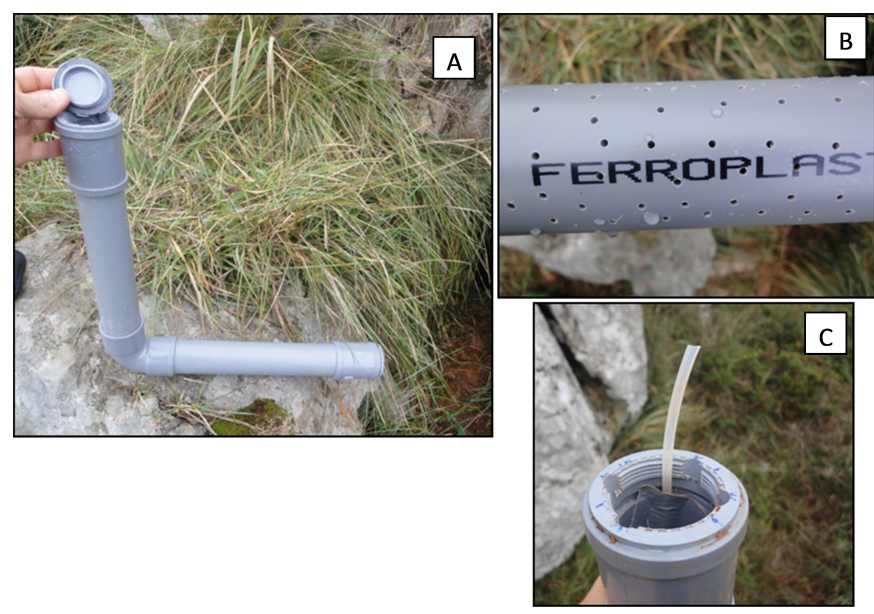

Fig. 3. Image of the soil sampling device (a) showing both the perforated lower section which enables air exchange between the soil and the tube (b) and the silicon tube used for extracting gas samples from the base of the soil zone (c).

Carbon isotope $\left(\delta^{13} \mathrm{C}\right)$ analysis of soil and cave air was undertaken between December 2011 and October 2013 on a monthly basis. Soil air samples were extracted from the base of the soil sampling device via a small diameter silicon tube which was pre-fixed into the sampler (Fig. 3). Air was then extracted using a $20 \mathrm{ml}$ syringe and injected into a $12 \mathrm{ml}$ pre-evacuated glass exetainer. Cave and external air was sampled in a similar fashion using a $20 \mathrm{ml}$ syringe, injecting air directly into the pre-evacuated glass exetainer. External air samples from immediately adjacent to the cave entrance were collected on five occasions between 2011 and 2013 to give a baseline external $\delta^{13} \mathrm{C}$ in $\mathrm{CO}_{2}$. $\delta^{13} \mathrm{C}$ in all samples were analysed at the NERC Life Sciences Mass Spectrometry Facility, Lancaster node,
CEH Lancaster, using a GV Instruments Tracegas Preconcentrator coupled to an Isoprime IRMS. Analytical errors were reported at one standard deviation as $0.16 \%$, and are reported relative to VPDB.

\section{Modern carbonate deposits}

Modern carbonate samples were collected by removing the top $100 \mu \mathrm{m}$ of two actively depositing speleothems (ASM and ASR, Fig. 2), and also using a glass plate to collect modern carbonate deposition integrated over a full annual cycle on the top of a third actively growing speleothem (ASF, Fig. 2). This carbonate was subsequently analysed for carbon and oxygen isotopes at the Stable Isotope Facilities, British Geological Survey, using an IsoPrime isotope ratio mass spectrometer with Multiprep device; average $2 \sigma$ uncertainty is $0.07 \%$. Isotope values are reported relative to the international VPDB standard.

\section{RESULTS}

\section{Rainfall dynamics in Matienzo}

North western Iberian climate is dominated by its close proximity to the North Atlantic Ocean, setting this region apart from more southerly areas of Spain, which are also influenced by Mediterranean sourced precipitation. During this study, approximately $80 \%$ of Matienzo's prevailing air masses tracked over the North Atlantic (Fig. 4), associated with westerly frontal systems (calculated via HYSPLIT modelling; Baldini et al., 2010; Draxler \& Rolph, 2010). The air mass history of each rainfall event was calculated using five-day (120-h) kinematic back trajectories originating from Matienzo $\left(43^{\circ} 31^{\prime} \mathrm{N},-3^{\circ} 58^{\prime} \mathrm{W}\right)$, for more detailed methodology see Baldini et al. (2010). These models originate at the end of each rainfall collection day to encapsulate the whole rainfall event, this is essential as the peak rainfall period is unknown. Rainfall for three atmospheric levels was computed (850, 700 and 500 hecto-pascals, hPa) approximately 1500, 3015 and 5575 masl (Baldini et al., 2010). As suggested by the Air Resources Laboratory (ARL) [part of National Oceanographic and Atmospheric Administration (NOAA)], atmospheric levels of 850 and $700 \mathrm{hPa}$ were used for modelling to give a good approximation of where frontal and synoptic rainfall is delivered (Baldini et al., 2010). The en-route uptake of moisture over the North Atlantic has been shown to be a major source of precipitation for sites in Western Europe (Baldini et al., 2010), as expected in Matienzo (Fig. 4). However, moisture delivery from the North Atlantic source region varies on a range of temporal scales, often influenced by atmospheric modes such as the North Atlantic Oscillation (NAO), Scandinavian pattern and a local expression of the East Atlantic/Western Russian pattern (Baldini et al., 2008; Roberts et al., 2012; Baldini et al., 2015) and changes in North Atlantic conditions.

During the monitoring program, the Matienzo depression received approximately $1400 \mathrm{~mm} /$ year of precipitation. This is slightly higher than the 1050 $\mathrm{mm} /$ year received at the closest MET station in 


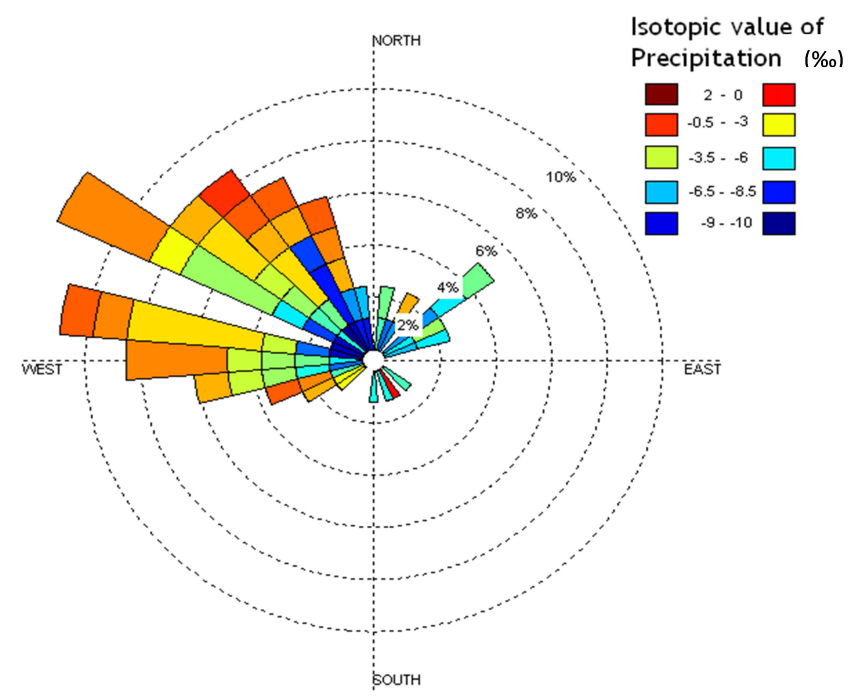

Fig. 4. Wind rose showing the direction from which air masses carrying rainfall to Matienzo originate and the oxygen isotope composition of the associated rainfall. The predominant trajectory of moisture bearing air masses is from the NW - W and this direction is associated with a full range of isotopic values. Source regions are broken into $10^{\circ}$ sectors and the $\%$ of rainfall from each sector is shown as dashed circles. Rainfall \% from each sector was calculated following back trajectory analysis using the Hybrid Single-Particle Lagrangian Integrated Trajectory (HYSPLIT) Model (Version 4.8) (Draxler \& Rolph, 2010) and following a similar methodology to Baldini et al. (2010).

Santander (IAEA, 2014). Peak monthly rainfall was measured in February 2013 (300 mm/month) and a monthly low of $20 \mathrm{~mm}$ recorded in August 2012. Precipitation mainly fell during the winter, with water excess being dominant (Thornthwaite, 1948) during November - April each year.

Rainfall stable isotope monitoring shows $\delta^{18} \mathrm{O}$ values which range from -16.5 to $+4.5 \%$ o (mean $=-4.9 \%$; $20=6.1 \%$; $n=198$ ) and $\delta^{2} \mathrm{H}$ ranging from -130.7 to $+12.8 \%$ o (mean $=-27.4 \%$; $2 \sigma=43.8 \%$; $n=195)$. Producing a local meteoric water line of rainfall collected in Matienzo with a slope of 6.86 and an intercept of 5.8, slightly lower than the global meteoric water line ( slope $=8.0 ;$ intercept $=10)$. On the monthly scale, the $\delta^{18} \mathrm{O}$ composition of rainfall in the Matienzo depression (monthly weighted mean) was strongly regulated by a rainfall amount effect (Pearson correlation; $\mathrm{r}^{2}=0.51 ; \mathrm{p}<0.01$ ), with more negative isotopic values related to higher rainfall amounts (Fig. 5) and to a lesser extent by temperature (Pearson correlation; $\left.\mathrm{r}^{2}=0.33 ; \mathrm{p}<0.01\right)$, where lower temperatures were related to more negative isotope values.

\section{Air temperature and carbon dioxide dynamics}

Average annual cave air temperature at $65 \mathrm{~m}$ underground in Cueva de Asiul (+13.7 $\pm 0.5^{\circ} \mathrm{C}$ ) was very similar to the average external air temperature $\left(+13.8^{\circ} \mathrm{C}\right)$, but with a temperature range of $1^{\circ} \mathrm{C}$ at $65 \mathrm{~m}$ depth. Within this range, a clear seasonality of temperature was observed (Fig. 6).

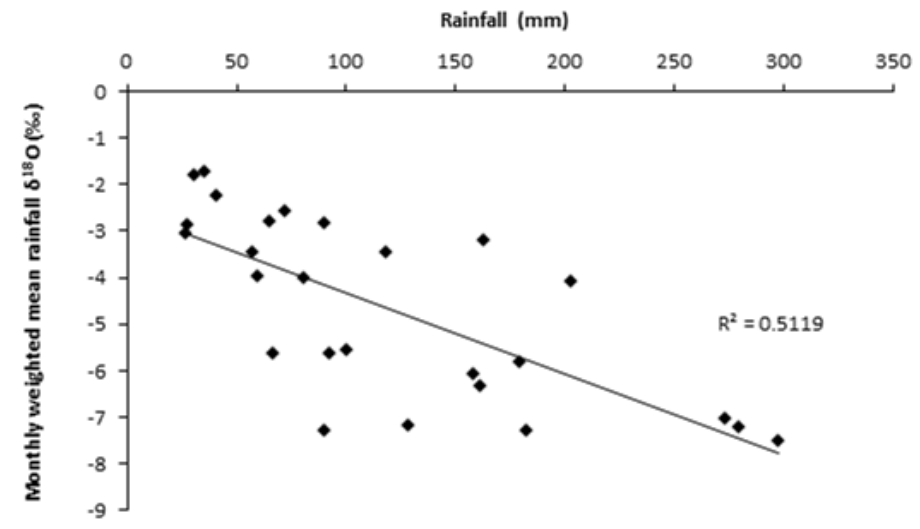

Fig. 5. The amount effect relationship in Matienzo rainfall calculated using monthly rainfall amount and weighted oxygen isotope measurements.

Summer (April to November) cave air temperatures were characterised by a gradual, stable increase from +13 to $+14^{\circ} \mathrm{C}$. Under winter conditions rapid reductions in cave temperature were observed, by up to $0.7^{\circ} \mathrm{C}$ (Fig. 6).

$\mathrm{CO}_{2}$ does not replicate with the same intensity of seasonality compared to that observed in the temperature records. Peak values of $\mathrm{CO}_{2}$ were measured in June 2013 (2090 ppm) and low values prevail during October 2012 (360 ppm; Fig. 6). Much stronger seasonality was observed in soil air $\mathrm{CO}_{2}$ measured on a monthly basis, demonstrating peak concentrations (4283 $\mathrm{ppm})$ during the summer and low values (647 ppm) during the winter (Fig. 6).

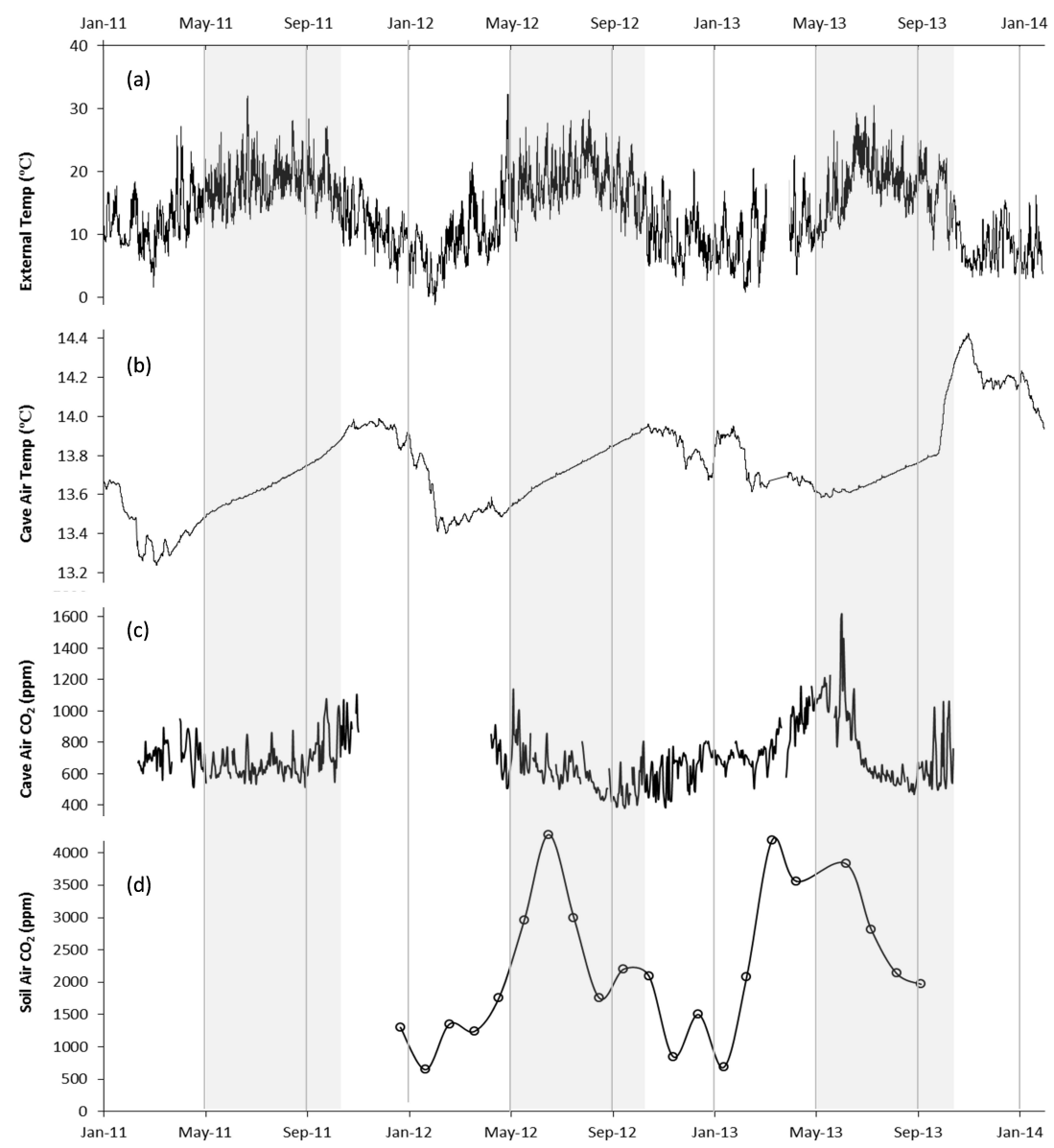

Fig. 6. Cave and climate monitoring data from January 2011 to January 2014. (a) external air temperature measured $250 \mathrm{~m}$ from the cave entrance ( 35 point running mean); (b) cave air temperatures measured at $65 \mathrm{~m}$ underground, hanging logger (35 point running mean); (c) hourly resolution cave air and (d) soil air $\mathrm{CO}_{2}$ concentrations (monthly resolution). Grey bands indicate the summer season (May - October). 


\section{Speleothem drip waters}

All speleothem drip sites displayed constant dripping throughout the study years and a distinct seasonality in drip discharge. Peak discharge amounts varied between the speleothems but discharge maxima (0.91 1/day at ASF based upon an average drip volume $=0.076 \mathrm{ml}$ ) occurred at all sites during the winter. The summers were characterised by gradually decreasing drip rates (min 0.14 1/day at $\mathrm{ASF}$ ) under dryer karst conditions at all sites, followed by a very rapid return to higher rates at the onset of seasonal rainfall. Superimposed upon this seasonal signal are discrete spikes in speleothem discharge which can range up to an additional 70 drips per hour (an additional $<5.5 \mathrm{ml} /$ hour). $\delta^{18} \mathrm{O}$ analysis of speleothem ASF drip waters showed a range between -5.3 and $-6.9 \%$ with an average value of $-6.08 \%$ o $(n=155)$.

\section{DISCUSSION}

\section{Cave air temperature and ventilation dynamics}

In Cueva de Asiul, patterns of cave air temperature closely resemble the seasonality of external temperature cycles (Fig. 6), indicating a dominant air density control upon ventilation regime (Wigley \& Brown, 1976; Smith et al., 2015). During the summer this temperature record is buffered by bedrock heating, resulting in a steady and uninterrupted rise in cave air temperatures (Fig. 6). Under winter conditions, external air temperature drops significantly, and therefore transgresses more frequently below the cave internal temperature threshold, meaning colder external air can flow into the cave system over more of the diurnal cycle. Cold external air overwhelms the effect of bedrock heating, forcing cave air temperatures to remain low throughout the coldest part of the winter season (Fig. 6). At the end of the winter, cave air temperatures begin to rise several weeks before any observed increase in external temperature (Fig. 6) (Smith et al., 2015). This process is driven by a combination of cave air stagnation, as external air temperatures become very close to those internal to the cave environment, and the conduction of heat through surrounding bedrock, warming the cave air (Smith et al., 2015).

$\mathrm{CO}_{2}$ levels remain low within the cave during the summer, indicating a lack of $\mathrm{CO}_{2}$ build up. $\mathrm{CO}_{2}$ build up is thwarted in Cueva de Asiul by diurnal ventilation of the cave (Smith et al., 2015). External diurnal temperature transgressions over the cave internal temperature threshold thereby keep $\mathrm{CO}_{2}$ levels within the cave low throughout the summer.

High resolution $\mathrm{CO}_{2}$ and cave air pressure monitoring have also identified an event scale ventilation process which can occur at any point of the year, independent of the dominant temperature driven ventilation. This secondary ventilation regime is driven by changes in external air pressure (Genty \& Deflandre, 1998) which create a pressure gradient between the cave and external air (Smith et al., 2015). When external pressure is low, this imbalance causes air to flow rapidly out of the cave system, aiding the drawdown of karst and soil air on an event (hourly) scale. This pressure driven process causes small scale perturbations to cave air $\mathrm{CO}_{2}$ content due to the high $\mathrm{pCO}_{2}$ content of air within the soil zone being drawn into the cave.

To further assess the sources of $\mathrm{CO}_{2}$ in Cueva de Asiul, monitoring for $\delta^{13} \mathrm{C}$ in $\mathrm{CO}_{2}$ was undertaken on a monthly basis, both within the cave but also in the soil zone (Fig. 6) and using external air samples. The highest cave air $\delta^{13} \mathrm{C}$ measurements $(-10.9 \%$ ) are similar to those taken in the open atmosphere $(-8.9 \%$ o) highlighting the importance of external air ventilation even at $65 \mathrm{~m}$ depth into the cave (Fig. 7). The lowest $\delta^{13} \mathrm{C}$ in cave air $\mathrm{CO}_{2}(-16 \%$ ) indicates a $\mathrm{CO}_{2}$ source enriched in ${ }^{12} \mathrm{C}$, with mixing model end member values calculated as low as $-46 \%$ (Fig. 7 ). This calculated end member is lower than either the measured soil $\delta^{13} \mathrm{C}(-21 \%)$ or the calculated soil zone end members $(-34 \% \circ)$. The very low $\delta^{13} \mathrm{C}$ values calculated in this mixing model potentially indicate microbial oxidation of methane within the soil, upper karst or a ground air component (Mattey et al., 2013; Mattey et al., 2010).

$\delta^{13} \mathrm{C}$ in $\mathrm{CO}_{2}$ and cave temperature highlight the importance of two key processes in controlling the composition of cave air. These are 1 . ventilation of the cave chamber with external air, and 2. draw down of 'ground air' through the karst. These two processes combine, creating a relatively low $\mathrm{pCO}_{2}$ environment year round, meaning that speleothem deposition is not systematically limited for long periods during any one season.

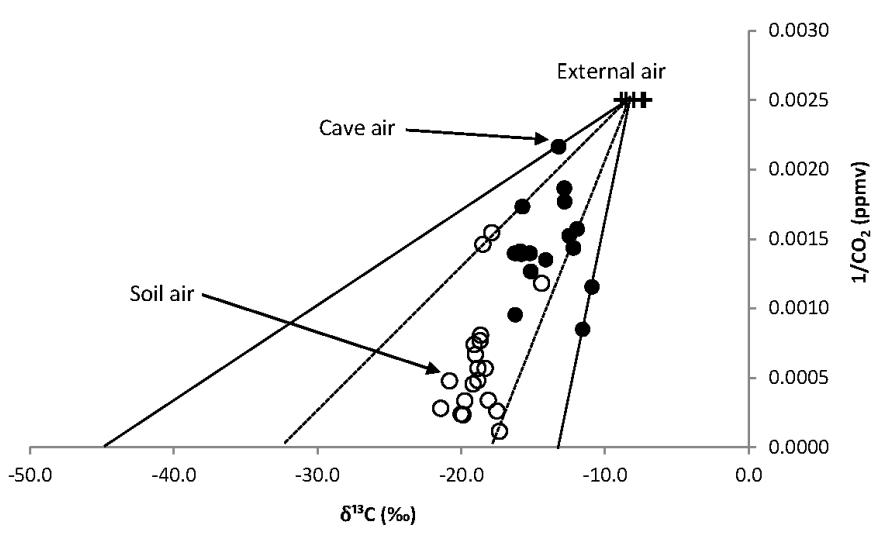

Fig. 7. Keeling plot showing the carbon isotope value of cave and soil air in comparison to the $\mathrm{CO}_{2}$ concentration of that air $\left(1 / \mathrm{pCO}_{2}\right)$. Atmospheric samples act as a heavy end member to this isotopic system whilst the other end members can be calculated as the position where straight lines intercept the $x$ axis. Black crosses are measured external air samples, open circles are soil air samples and closed black circles are cave air samples.

\section{Karst recharge dynamics}

Rainfall isotope monitoring highlights a strong amount effect in modern precipitation at this site (Fig. 5). However, the degree to which external rainfall dynamics are preserved within speleothem calcite demands an understanding of the karst hydrological system.

Drip monitoring studies in Cueva de Asiul show that speleothems are constantly supplied with supersaturated karst water, facilitating year round carbonate deposition. Water excess calculations indicate that these karst waters are sourced primarily 
from winter rainfall, with evapotranspiration limiting the ingress of summer rainfall to only the largest events (Fig. 8). Significant homogenisation of rainfall within the karst is however thought to partially obscure the $\delta^{18} \mathrm{O}$ of the summer events.

Drip water $\delta^{18} \mathrm{O}$ collected within the cave $\left(\delta^{18} \mathrm{O}_{\text {drip }}\right.$ range $=-5.5$ to $-7.0 \%$ o) offer a muted range of isotope values from those observed in annual rainfall $\delta^{18} \mathrm{O}_{\text {rainfall }}$ (range $=+4.5$ to $-16.5 \%$ ), indicating that karst water mixing was sufficient to homogenise water isotope values. When compared to the local winter meteoric water line for Matienzo (Fig. 9), cave drip water $\delta^{18} \mathrm{O}_{\text {drip }}$ cluster around the average winter rainfall $\delta^{18} \mathrm{O}$ values of the preceding year $\left(2010-11\right.$ rainfall $\delta^{18} \mathrm{O}=-5.9 \%$, drip water $=-6.4 \%$; $2011-12$ rainfall $\delta^{18} \mathrm{O}=-5.5 \%$, drip water $=-5.8 \%$; $2012-2013$ rainfall $\delta^{18} \mathrm{O}=-6.6 \%$, drip water $-6.2 \%$ o). This suggests that water percolation through the karst preserves external rainfall $\delta^{18} \mathrm{O}$, and that speleothem $\delta^{18} \mathrm{O}$ should offer an accurate proxy of variable rainfall amounts in northern Iberia. Longer term monitoring of cave drip waters is required to confirm the preservation of annual rainfall trends on drip water $\delta^{18} \mathrm{O}$ over decadal or longer scales. Palaeoclimate records from this cave should therefore be ideally suited to record longer term changes in rainfall amount to this region, possibly regulated by changes within the major rainfall source region, the North Atlantic.

\section{Transfer of climate signals into modern carbonate deposits}

Karst processes are shown to effectively transfer an average $\delta^{18} \mathrm{O}$ signal to the site of speleothem growth (Fig. 9). To ensure that this signal is accurately incorporated into depositing carbonate, we analyse the $\delta^{18} \mathrm{O}$ in modern carbonate from both the very top of speleothem deposits (ASR and ASM) and calcite

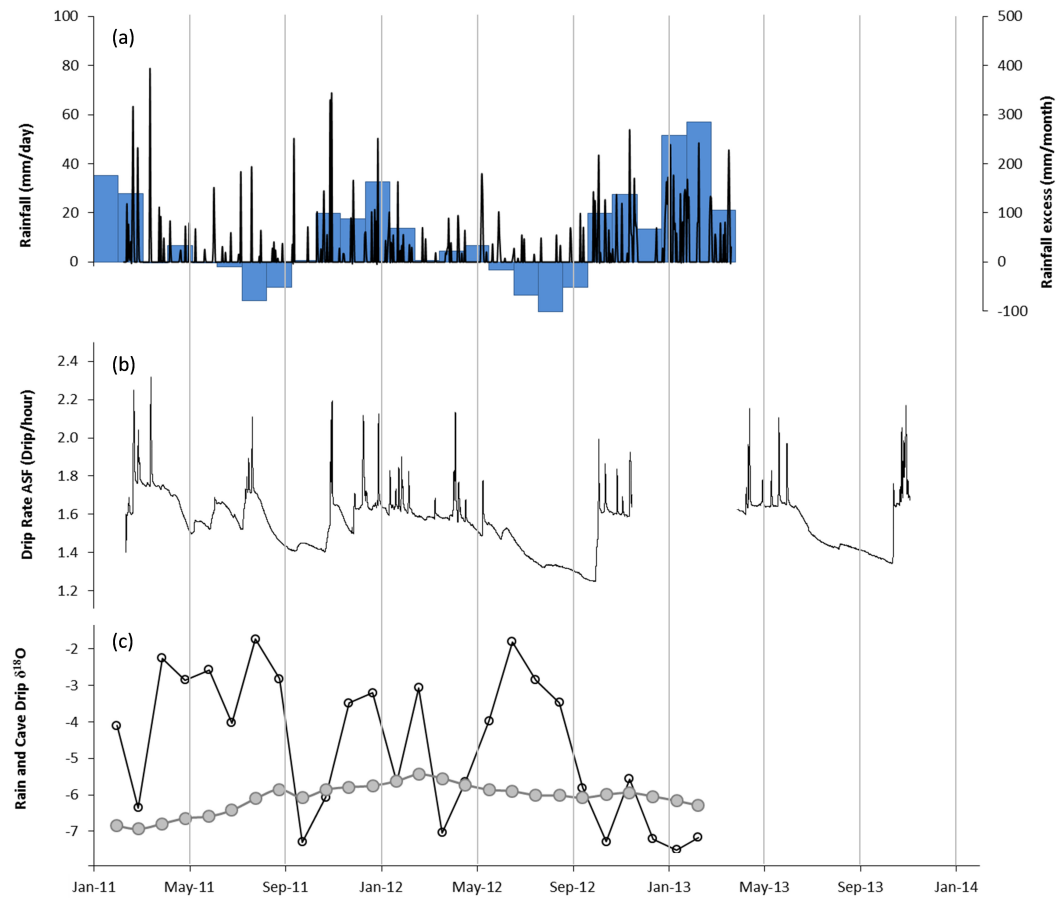

Fig. 8. (a) Daily rainfall amount (black line) and monthly water excess (blue bars) presented alongside (b) speleothem (ASR) drip rate and (c) amount weighted oxygen isotope values of rainfall and bulk collection speleothem drip water.

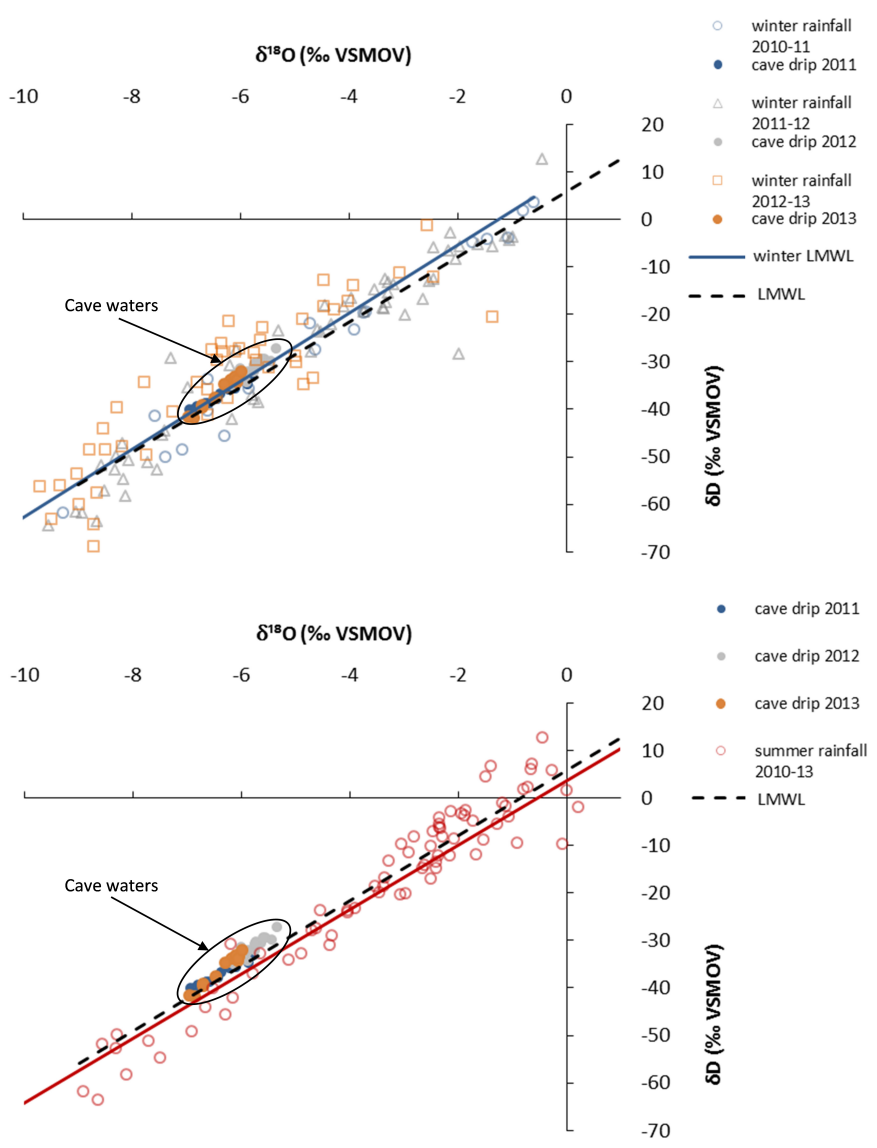

Fig. 9. Rainfall and cave drip water data. Top panel - Local Meteoric Water Line (LMWL) is shown in black dash whilst the winter MWL is shown in blue, rainfall from winter 2010-11 (open blue circles) is associated with cave drip water from 2011 (closed blue circles) the same is true for winter rainfall 2011-12 (open grey triangles) and drip water in 2012 (closed grey circles) and winter rainfall 2012-13 (open orange squares) and cave drip water 2012 (closed orange circles). Bottom panel - LMWL is shown in black dash as is the summer MWL (red line) associated with the full range of summer rainfall events from 2010-13 (open red circles), closed circles represent cave drip waters as explained form the top panel. Cave drip waters are clearly associated with winter rainfall isotope values (blue line), sitting away from the summer MWL (red line).

grown on artificial substrates (on top of ASF). Average drip water $\delta^{18} \mathrm{O}(-6.08 \%$, $1 \mathrm{stdv}=$ $0.4 \%$ ) is compared to modern speleothem carbonate $\delta^{18} \mathrm{O}(-5.1 \pm 0.32 \%$ o $)$ and calcite plate carbonate $\delta^{18} \mathrm{O}(-5.12 \pm 0.34 \%$ ) , at the average cave temperature of $13.7^{\circ} \mathrm{C}$, using the experimentally derived fractionation factor of Tremaine et al. (2011):

$$
1000 \ln \alpha=(16.1 \pm 0.65)\left[10^{3} \mathrm{~T}^{-1}\right](-24.6 \pm 2.2)
$$

This fractionation factor has proved more effective at calculating real in cave $\delta^{18} \mathrm{O}$ fractionation between drip water and speleothem calcite than laboratory based calculations and presents a range of $\delta^{18} \mathrm{O}$ fractionation at which palaeoclimate reconstructions may be made (Tremaine et al., 2011). $\delta^{18} \mathrm{O}$ of speleothems from Cueva de Asiul fall within error of this fractionation coefficient, indicating that the oxygen isotope deposition environment in Cueva de Asiul is similar to other cave sites from around the World (Tremaine et al., 2011). This suggests 
that calcite deposition in Cueva de Asiul is ideal for accurate palaeoclimate reconstruction.

\section{CONCLUSION}

Cave monitoring in Cueva de Asiul focused on understanding the growth environment for speleothems that have been extracted for palaeoclimate reconstruction. The cave has a complex ventilation system driven by diurnal changes in external temperature and air pressure, resulting in relatively low cave air $\mathrm{pCO}_{2}$, which promotes the growth of speleothems year round. Super-saturated waters entering the cave preserve a smoothed rainfall $\delta^{18} \mathrm{O}$ signature and precipitate speleothem carbonate under similar fractionation conditions as other cave sites. Speleothems from this cave are therefore thought ideal for preserving records of rainfall amount and may potentially offer insights into changes in the Cave's major rainfall source region, the North Atlantic.

\section{ACKNOWLEDGEMENTS}

This work was supported by NERC studentship grant NE/I527953/1 and Lancaster University. Cave monitoring was undertaken with kind permission from Gobierno de Cantabria, Cultura. Special thanks for field work to Pete Smith, Andy Quin and the Matienzo caving expedition and to Dave Hughes for isotope analysis. Thanks go to three anonymous reviewers whose comments have helped to make this a better paper.

\section{REFERENCES}

Baker A., Barnes W.L. \& Smart P.L., 1997 - Variations in the discharge and organic matter content of stalagmite drip waters in Lower Cave, Bristol. Hydrological Processes, 11: 1541-1555.

http://dx.doi.org/10.1002/(SICI)1099-1085(199709) 11:11<1541::AID-HYP484>3.0.CO;2-Z

Baldini J.U.L., 2010 - Cave atmospheric controls on stalagmite growth rate and palaeoclimate records. In: Pedley H.M. \& Rogerson M. (Eds.), Tufas and Speleothems: Unravelling the microbial and physical controls. Geological Society, London, Special Publications, 336: 283-294.

Baldini L.M., McDermott F., Foley A.M. \& Baldini J.U.L., 2008 - Spatial variability in the European winter precipitation $\delta^{18} \mathrm{O}-\mathrm{NAO}$ relationship: Implications for reconstructing NAO-mode climate variability in the Holocene. Geophysical Research Letters, 35: L04709. http:/ / dx.doi.org/10.1029/2007GL032027

Baldini L.M., McDermott F., Baldini J.U.L., Arias P., Cueto M., Fairchild I.J., Hoffmann D.L., Mattey D.P., Müller W., Constantin Nata D., Ontañón R., Garciá-Moncó C. \& Richards D.A., 2015 - Regional temperature, atmospheric circulation, and sea-ice variability within the Younger Dryas Event constrained using a speleothem from northern Iberia. Earth and Planetary Science Letters, 419: 101-110. http://dx.doi.org/10.1016/j.eps1.2015.03.015

Corrin J. \& Smith P., 2010 - Matienzo 50 years of speleology. Matienzo Caves, Lancashire.

Dominguez-Villar D., Fairchild I.J., Baker A., Wang X., Edwards L.R. \& Cheng H., 2009 - Oxygen isotope precipitation anomaly in the North Atlantic region during the 8.2 ka event. Geology, 37: 1095-1098.

http://dx.doi.org/10.1130/G30393A.1
Dreybrodt W., 1999 - Chemical kinetics, speleothem growth and climate. Boreas, 28: 347-356.

http:/ / dx.doi.org/10.1111/j.1502-3885.1999.tb00224.x

Fairchild I.J., Tuckwell G.W., Baker A. \& Tooth A.F., 2006 - Modelling of dripwater hydrology and hydrogeochemistry in a weakly karstified aquifer (Bath, UK): Implications for climate change studies. Journal of Hydrology, 321: 213-231. http://dx.doi.org/10.1016/j.jhydrol.2005.08.002

Fairchild I.J. \& Baker A., 2012 - Speleothem Science. Wiley-Blackwell, Sussex, UK.

Genty D. \& Deflandre G., 1998 - Drip flow variations under a stalactite of the Père Noël cave (Belgium). Evidence of seasonal variations and air pressure constraints. Journal of Hydrology, 211: 208-232.

http://dx.doi.org/10.1016/S0022-1694(98)00235-2

Gimeno L., Drumond A., Nieto R., Trigo R.M. \& Stohl A., 2010 - On the origin of continental precipitation. Geophysical Research Letters, 37: L13804. http://dx.doi.org/10.1029/2010GL043712

IAEA/WMO., 2014 - Global Network of Isotopes in Precipitation. The GNIP Database. Accessible at: http:// www.iaea.org/water

Lopez-Merino L., Cortizas A.M. \& Lopez-Saez J.A., 2010 Early agriculture and palaeoenvironmental history in the North of the Iberian Peninsula: a multi-proxy analysis of the Monte Areo mire (Asturias, Spain). Journal of Archaeological Science, 37: 1978-1988.

http://dx.doi.org/10.1016/j.jas.2010.03.003

Martin-Chivelet J., Muños-Garcia M.B., Edwards R.L., Turrero M.J. \& Ortega A.I., 2011 - Land surface temperature changes in Northern Iberia since $4000 \mathrm{yr}$ $B P$, based on $\delta^{13} \mathrm{C}$ of speleothems. Global and Planetary Change, 77: 1-12.

http://dx.doi.org/10.1016/j.gloplacha.2011.02.002

Mattey D., Fairchild I.J., Atkinson T.C., Latin J-P., Ainsworth M. \& Durell R., 2010 - Seasonal microclimate control of calcite fabrics, stable isotopes and trace elements in modern speleothem from St Michaels Cave, Gibraltar. In: Pedley H.M. and Rogerson M. (Eds.), Tufas and Speleothems: Unravelling the microbial and physical controls. Geological Society, London, Special Publications, 336: 283-294.

http://dx.doi.org/10.1144/sp336.17

Mattey D.P., Fisher R., Atkinson T.C., Latin J.-P., Durrell R., Ainsworth M., Lowry D. \& Fairchild I.J., 2013 Methane in underground air in Gibraltar karst. Earth and Planetary Science Letters, 374: 71-80.

http://dx.doi.org/10.1016/j.eps1.2013.05.011

Martínez-García B., Bodego A., Mendicoa J., Pascual A. \& Rodríguez-Lázaro J., 2014 - Late Quaternary (Marine Isotope Stage 3 to Recent) sedimentary evolution of the Basque shelf (southern Bay of Biscay). Boreas, 43 (4): 973-988.

http://dx.doi.org/10.1111/bor.12079

Martínez-García B., Rodríguez-Lázaro J., Pascual A. \& Mendicoa J., 2015 - The "Northern guests" and other palaeoclimatic ostracod proxies in the late Quaternary of the Basque Basin (S Bay of Biscay). Palaeogeography, Palaeoclimatology, Palaeoecology, 419: 100-114. http://dx.doi.org/10.1016/j.palaeo.2014.06.032

Martinez-Pillado V., Aranburu A., Arsuaga J.L., RuizZapata B., Gil-Garcia M.J., Stoll H., Yusta I., Iriarte E., Carretero J.M., Edwards R.L. \& Cheng H., 2014 - Upper Pleistocene and Holocene palaeoenvironmental records in Cueva Major karst (Atapuerca, Spain) from different proxies: speleothem crystal fabrics, palynology and archaeology. International Journal of Speleology, 43 (1): 1-14. http://dx.doi.org/10.5038/1827-806X.43.1.1 
McDermott F., 2004 - Palaeo-climate reconstruction from stable isotope variations in speleothems: a review. Quaternary Science Reviews, 23: 901-918. http://dx.doi.org/10.1016/j.quascirev.2003.06.021

McDermott F., Atkinson T.C., Fairchild I.J., Baldini L.M. \& Mattey D.P., 2011 - A first evaluation of the spatial gradients in $\delta^{18} \mathrm{O}$ recorded by European Holocene speleothems. Global and Planetary Change, 79: 275-287. http://dx.doi.org/10.1016/j.gloplacha.2011.01.005

Mojtahid M., Jorissen F.J., Schiebel R., Michel E., Eynaud F., Gillet H., Cremer M., Ferreiro P.D, Siccha M. \& Howa H., 2013 - High resolution Holocene record in the southeastern Bay of Biscay: Global versus regional climate signals. Palaeogeography, Palaeoclimatology, Palaeoecology, 377: 28-44.

http://dx.doi.org/10.1016/j.palaeo.2013.03.004

Morellón M., Valero-Garcés B.L., Vegas-Vilarrŭbia T., González-Sampériz P., Romero O., Delgado-Huertas A., Mata P., Moreno A., Rico M. \& Corella J.P., 2009 Lateglacial and Holocene palaeohydrology in the western Mediterranean region: the Lake Estanya record (NE Spain). Quaternary Science Reviews, 28: 2582-2599. http://dx.doi.org/10.1016/j.quascirev.2009.05.014

Moreno A., Stoll H., Jiménez-Sánchez M., Cacho I., Valero-Garcés B.L., Ito E. \& Edwards R.L., 2010 - A speleothem record of glacial $(25-11.6 \mathrm{kry} B P$ ) rapid climatic changes from northern Iberian Peninsula. Global and Planetary Change, 71: 218-231.

http://dx.doi.org/10.1016/j.gloplacha.2009.10.002

Quin A., 2010 - Matienzo Geomorphology. In: Corrin J. \& Smith P. (Eds.), Matienzo 50 years of speleology: 291-928.

Roberts N., Moreno A., Valero-Garés B., Pablo Corella J., Jones M., Allcock S., Woodbridge J., Morellón M., Luterbacher J., Xoplaki E. \& Türkes M., 2012 Palaeolimnological evidence for an east-west climate see-saw in the Mediterranean since AD 900. Global and Planetary Change, 84-85: 23-34.

http://dx.doi.org/10.1016/j.gloplacha.2011.11.002
Smith A.C., Wynn P.M., Barker P.A. \& Leng M.J., 2015

- Drip water electrical conductivity as an indicator of cave ventilation at the event scale. Science of the Total Environment, 532: 517-527.

http://dx.doi.org/10.1016/j.scitotenv.2015.06.037

Spötl C., Fairchild I.J. \& Tooth A.F., 2005 - Cave air control on dripwater geochemistry, Obir Caves (Austria): Implications for speleothem deposition in dynamically ventilated caves. Geochimica et Cosmochimica Acta, 69 (10): 2451-2468.

http://dx.doi.org/10.1016/j.gca.2004.12.009

Stoll H.M., Moreno A., Mendez-Vicente A., GonzalezLemon S., Jimenez-Sanchez M., Dominguez-Cuesta M.J., Edwards R.L., Cheng H. \& Wand X., 2013 Palaeoclimate and growth rates of speleothems in the northwestern Iberian Peninsula over the last two glacial cycles. Quaternary Research, 80: 284-290.

http://dx.doi.org/10.1016/j.yqres.2013.05.002

Thornthwaite C.W., 1948 - An approach toward a rational classification of climate. Geophysical Review, 38: $55-94$.

http://dx.doi.org/10.2307/210739

Tremaine D.M., Froelich P.N \& Wang Y., 2011 - Speleothem calcite farmed in situ: Modern calibration of $\delta^{18} \mathrm{O}$ and $\delta^{13} \mathrm{C}$ palaeoclimate proxies in a continuously-monitored natural cave system. Geochimica et Cosmochimica Acta, 75: 4929-4950.

http://dx.doi.org/10.1016/j.gca.2011.06.005

Waltham A.C., 1981 - The Karstic evolution of the Matienzo depression, Spain. Zeitschrift für Geomorphologie, 23 (3): 300-312.

Wigley T.M.L. \& Brown M.C., 1976 - The physics of caves. In: Ford T.D. \& Cullingford C.H.D (Eds.), The Science of Speleology, Academic Press, London, 329-358. 